\title{
Clenbuterol Storage Stability in the Bovine Urine and Liver Samples Used for European Official Control in the Azores Islands (Portugal)
}

\author{
Isabel Pinheiro, ${ }^{\dagger}$ Bruno Jesuino, ${ }^{\ddagger}$ Jorge Barbosa,${ }^{\ddagger}$ Humberto Ferreira, ${ }^{\S}$ \\ Fernando Ramos, ${ }^{*}$ "I José Matos, ${ }^{\perp}$ and Maria Irene Noronha da Silveira" \\ Laboratório Regional de Veterinária, Direcção de Serviços de Veterinária, Direcção Regional do \\ Desenvolvimento Agrário, Vinha Brava, 9700-236 Angra do Heroísmo, Açores, Portugal, Laboratório \\ Nacional de Investigação Veterinária, Estrada de Benfica, 701-1549-011 Lisboa, Portugal, Faculdade \\ de Farmácia da Universidade de Lisboa, Av. Prof. Gama Pinto, 1649-003 Lisboa, Portugal, Grupo de \\ Bromatologia, Centro de Estudos Farmacêuticos, Faculdade de Farmácia da Universidade de Coimbra, \\ 3000-295 Coimbra, Portugal, and Centro de Biotecnologia dos Açores, Departamento de Ciências \\ Agrárias, Universidade dos Açores, Terra-Chã, 9701-851 Angra do Heroísmo, Portugal
}

\begin{abstract}
Clenbuterol is a well-known growth promoter, illegally used in farm animals, especially in cattle. Samples collected for the screening of $\beta_{2}$-agonist residues in Portuguese Azores Islands must travel through all the nine islands until they reach Azores Central Laboratory. If any suspicious sample is detected, it must be further transported to the National Reference Laboratory in Lisbon for confirmation. As a consequence of these circumstances, samples are submitted to different transport and storage times, as well as different temperature conditions and in some cases successive freezing and thawing cycles. As clenbuterol is the most detected $\beta_{2}$-agonist growth promoter in the Portuguese Residue Monitoring Plan, studies were conducted on the stability of this compound in incurred samples (bovine liver and urine) at $+4,-20$ and $-60^{\circ} \mathrm{C}$ over time. Samples kept at $-20^{\circ} \mathrm{C}$ were also analyzed over time after successive freezing and thawing cycles. The analyses of clenbuterol over time were performed by gas chromatography-mass spectrometry (GC-MS) with selected ion monitoring (SIM). Clenbuterol in incurred urine and liver samples was significantly stable up to 20 weeks at -20 and $-60{ }^{\circ} \mathrm{C}$ and after, at least, six consecutive freezings and thawings. At $+4{ }^{\circ} \mathrm{C}$, clenbuterol remained stable, at least until 12 weeks in urine and up to 20 weeks in liver.
\end{abstract}

KEYWORDS: Clenbuterol; urine; liver; stability; GC-MS

\section{INTRODUCTION}

Clenbuterol [4-amino-3,5-dichloro- $\alpha$-(tert-butylaminomethyl)benzyl alcohol] is an orally active $\beta_{2}$-agonist authorized for clinical use in veterinarian medicine as bronchodilatant in bovines, equines and pets, or as a tocolitic in cows with a maximum residue level (MRL) of $0.5 \mu \mathrm{g} \mathrm{kg}^{-1}$ for liver/kidney and $0.1 \mu \mathrm{g} \mathrm{kg}^{-1}$ for muscle or $0.05 \mu \mathrm{g} \mathrm{kg}^{-1}$ for milk $(1-3)$. It was observed in several animal species that $\beta_{2}$-agonist compounds, especially clenbuterol, could act as a repartitioning agent and was able to decrease fat deposition with enhanced protein accumulation when administered orally at high doses. This growth promoting property of $\beta_{2}$-agonists is still used in intensive production of cattle and other farm animals around

* Corresponding author: fjramos@ci.uc.pt, tel.: + 351239859994 , fax: + 351239827126.

† Direcção Regional do Desenvolvimento Agrário.

* Laboratório Nacional de Investigação Veterinária.

${ }^{\S}$ Faculdade de Farmácia da Universidade de Lisboa.

"Faculdade de Farmácia da Universidade de Coimbra.

${ }^{\perp}$ Universidade dos Açores. the world (2). Within the European Union (EU) their use as growth promoting agents is banned since 1996. The ingestion of contaminated edible tissues containing residues of such compounds has been responsible for several human intoxications in some European countries $(4-8)$ including Portugal $(9,10)$.

Control of the illegal use of $\beta_{2}$-agonists as well as other veterinary drugs and growth promoters, in intensive animal production, is regularly performed within the EU by the application of Residue Monitoring Programs. The overall strategy of control includes the surveillance of live animals with the collection of urine, feed, water and edible tissues like muscle and liver at slaughterhouses.

Under the application of the Portuguese Residue Monitoring Plan in Azores Islands, $\beta_{2}$-agonist immunoassay screening tests, by enzyme-linked immunosorbent assay (ELISA), are performed in Azores Central Laboratory. For this task, urine and liver samples are collected in each of the nine islands and preserved under cold storage until transportation to the laboratory. If the transportation is performed in 24 to $48 \mathrm{~h}$ after collection, samples are maintained refrigerated at $+4{ }^{\circ} \mathrm{C}$. If not, samples are frozen 
at $-20{ }^{\circ} \mathrm{C}$ until transportation is made possible. At the laboratory, and until analysis, samples are stored under refrigeration $\left(+4{ }^{\circ} \mathrm{C}\right)$ or frozen conditions $\left(-20^{\circ} \mathrm{C}\right)$, for periods of time that can vary from one day to several weeks, depending on the number of samples available for analysis. If any suspicious sample is detected, analytical confirmation must be conducted according to the criteria of Commission Decision 2002/657/EC (11). Since confirmation is performed in Lisbon at Laboratório Nacional de Investigação Veterinária (LNIV), the National Reference Laboratory, samples must be subjected, once more, to freezing, storage and transportation until further analysis.

From this particular situation involving Portuguese Azorean islands and the control of $\beta_{2}$-agonist residues in live animals and their products emerges the question of the stability of these compounds in urine and liver samples submitted to storage time and temperature extreme conditions with several freezing and thawing cycles.

In the literature, a study performed on the storage stability of clenbuterol in incurred urine as Certified Reference Material concludes for the stability of the compound in this biological matrix (12). This study was performed with incurred lyophilized samples from which conclusions cannot be extrapolated to laboratory samples. Two other studies, using fortified urine samples instead of incurred urine, were found: in the first it was found that clenbuterol recovery diminished in urine during frozen storage at $-15^{\circ} \mathrm{C}(13)$, but in the second one no clenbuterol degradations occurred during storage at $-20^{\circ} \mathrm{C}$ or at $-60{ }^{\circ} \mathrm{C}(14)$.

For frozen incurred lyophilized liver samples with clenbuterol, similar studies were performed for the production of Certified Reference Material (15) and concluded in favor of the stability of the compound. The same conclusions were found for liver samples, when stored at $-30^{\circ} \mathrm{C}$ without any prehomogenization (16). Nevertheless, in a previous study it was also found that in prehomogenated liver clenbuterol was unstable at both -20 and $-60{ }^{\circ} \mathrm{C}(14)$.

Other studies $(17,18)$ demonstrated an elevated stability for clenbuterol during several processes of cooking tissues.

The aim of this paper was to study the stability of clenbuterol in incurred urine and liver samples under storage at $+4,-20$ and $-60{ }^{\circ} \mathrm{C}$ during 20 weeks, and under several freezing and thawing cycles at $-20{ }^{\circ} \mathrm{C}$, in an attempt to safeguard the analytical results of the official control.

\section{MATERIAL AND METHODS}

Reagents and Supplies. Clenbuterol was obtained from Sigma (St. Louis, MO), and the internal standard (IS) $d_{6^{-}}$ clenbuterol was provided by RIVM (Bilthoven, The Netherlands). The solid phase extraction (SPE) columns were from United Chemical Company (Bristol, PA) for urine (Clean Screen DAU 500) and for liver (Clean Screen DAU 1M6). The derivatizing reagent was composed of $N$-methyl- $N$-trimethylsililtrifluoroacetamide (MSTFA) from Macherey Nagel (Hoerdt, Germany), trimethyliodosilane (TMSI) from Sigma (Madrid, Spain) and dithioerythritol (DTI) from Merck (Darmstadt, Germany) [MSTFA/TMSI/DTI, 1000:2:2 (mL/mL/g)]. All other reagents were of analytical grade, and gases were supplied by Arliquid (Lisbon, Portugal).

Animal Treatment and Attainment of Incurred Samples. One Holstein cow $(500 \mathrm{~kg})$ was orally treated with clenbuterol: $7.5 \mu \mathrm{g}$ per $\mathrm{kg}$ b.w. per day for two days, and $3 \mu \mathrm{g}$ per $\mathrm{kg}$ b.w. per day for eight more days, in single doses. On the second day urine was collected, homogenized and separated in $10 \mathrm{~mL}$ aliquots in current polypropylene urine tubes (lot with 96 aliquots). After slaughter on the eleventh day, the liver $(9.1 \mathrm{~kg})$ was collected and separated in four strips after removal of $10 \mathrm{~g}$, in duplicate, from each one of the five liver lobes (19): lobus hepatis dexter (hd), lobus hepatis sinister (hs), lobus quadratus (lq), lobus caudatus (lc) and processus papillaris (pp).

Clenbuterol Homogeneity and Stability Studies. Nine random $10 \mathrm{~mL}$ aliquots of incurred urine and ten samples of $10 \mathrm{~g}$, two from each one of the five liver lobes, of incurred liver were analyzed fresh for previous homogeneity tests. Incurred urine aliquots and liver strips were stored at $+4,-20$ and $-60{ }^{\circ} \mathrm{C}$. Two sets of incurred urine aliquots and two sets of incurred liver strips were stored at $-20^{\circ} \mathrm{C}$. Subsequently 10 $\mathrm{mL}$ aliquots of incurred urine and $10 \mathrm{~g}$ of incurred liver were analyzed in triplicate at several storage times from each one of the storage conditions. One set of incurred urine and of incurred liver samples stored at $-20{ }^{\circ} \mathrm{C}$ were also analyzed after successive freezing and thawing cycles.

Extraction Procedures. The analytical procedure used for clenbuterol analysis is described elsewhere $(20,21)$. Briefly, to urine $(10 \mathrm{~mL})$ or liver $(10 \mathrm{~g})$ samples respectively 4.0 and 20.0 $\mathrm{mL}$ of $0.2 \mathrm{M}$ acetate buffer $\mathrm{pH} 5.2$ and $50 \mu \mathrm{L}$ of $\beta$-glucoronidase $\left(30 \mathrm{U} \mathrm{mL}^{-1}\right)$ /arylsulfatase $\left(60 \mathrm{U} \mathrm{mL}^{-1}\right)$ were added. As internal standard, $d_{6}$-clenbuterol $\left(5 \mathrm{ng} \mathrm{mL}^{-1}\right.$ in urine and $5 \mathrm{ng} \mathrm{g}^{-1}$ in liver) was added. Hydrolysis took place overnight at $45-50$ ${ }^{\circ} \mathrm{C}$. For liver samples an additional acid precipitation with 50 $\mathrm{mL}$ of hydrochloric acid was performed and the $\mathrm{pH}$ was brought to $6.0 \pm 0.3$ with $1 \mathrm{M}$ potassium hydroxide. Samples were then homogenized with $0.1 \mathrm{M}$ phosphate buffer $\mathrm{pH} 6$, and extracted using SPE columns. In summary, after sample centrifugation, the supernatant was decanted onto a CleanScreenDAU cartridge, previously preconditioned with methanol, water and phosphate buffer. The column was washed with acetic acid and methanol, and elution was done with an ethyl acetate/ammonium hydroxide solution $(97: 3, \mathrm{v} / \mathrm{v})$. Eluate was evaporated to dryness, under a current of dehydrated air, at $45{ }^{\circ} \mathrm{C}$, and the dry residue was kept in a desiccator, under vacuum, for at least $4 \mathrm{~h}$, until derivatization.

Derivatization. Dry eluates were derivatized with $50 \mu \mathrm{L}$ of MSTFA/TMSI/DTI at $65^{\circ} \mathrm{C}$ for $20 \mathrm{~min}$. They were left to cool to room temperature and transferred to the GC-MS system.

GC-MS Equipment and Parameters. Gas chromatography-mass spectrometry (GC-MS) analysis was performed on a Hewlett-Packard HP 6890 gas chromatograph coupled to a Hewlett-Packard HP 5973 quadrupole mass analyzer (HewlettPackard, Palo Alto, CA). An HP-5MS column (30 m × 0.25 mm i.d. $\times 0.25 \mu \mathrm{m}$ of film thickness, Agilent, Palo Alto, CA) was used. The mass spectrometer was operated in the electron impact (EI) mode and in selected ion monitoring (SIM) acquisition. Sample injection volume was $2 \mu \mathrm{L}$ (splitless, 1 min) with injector temperature at $230{ }^{\circ} \mathrm{C}$ using helium as carrier gas $\left(1.2 \mathrm{~mL} \mathrm{~min}^{-1}\right)$. Oven programmed temperature was as follows: $0.4 \mathrm{~min}$ at $100{ }^{\circ} \mathrm{C}$, up $10{ }^{\circ} \mathrm{C} \min ^{-1}$ to $200{ }^{\circ} \mathrm{C}$ (3 min), up $10^{\circ} \mathrm{C}$ $\min ^{-1}$ to $300{ }^{\circ} \mathrm{C}(5 \mathrm{~min})$, with the interface temperature kept at $320{ }^{\circ} \mathrm{C}$. Diagnostic ions used for detection and identification of clenbuterol as trimethylsilyl derivative were $\mathrm{m} / \mathrm{z} 86,300,335$, 337 and 405. For quantitative determination $\mathrm{m} / \mathrm{z}, 86$ and 92, respectively, for clenbuterol and $d_{6}$-clenbuterol were used.

Calibration Curves. For clenbuterol quantification a new calibration curve was used for each daily determination. These calibration curves were obtained with blank samples of urine and liver, free of clenbuterol, as verified by previous GC-MS analysis. The blank samples were spiked with clenbuterol at 4 to 6 concentration levels covering the range around the expected 


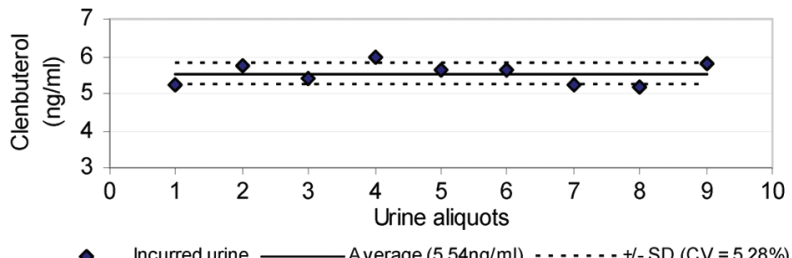

Figure 1. Homogeneity of clenbuterol concentration in the lot of incurred urine aliquots.

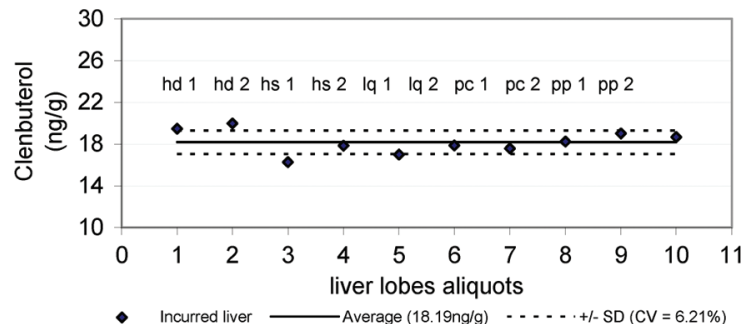

Figure 2. Homogeneity of clenbuterol distribution in five liver lobes: lobus hepatis dexter (hd), lobus hepatis sinister (hs), lobus quadratus (Iq), processus caudatus $(\mathrm{pc}$ ) and processus pappillaris (pp), with two determinations in each.

clenbuterol concentration, including one without any addition of clenbuterol (zero calibrant). These calibrants were also spiked with the same quantity of IS $d_{6}$-clenbuterol as the samples.

\section{RESULTS AND DISCUSSION}

The results of the homogeneity study of clenbuterol concentration in the urine lot and clenbuterol distribution in the liver are shown in Figures $\mathbf{1}$ and 2, and they demonstrate that the materials were homogeneous. The variability expressed as a coefficient of variation (CV) of mean and observed between individual aliquots of urine and between individual liver samples was very low, respectively $5.28 \%$ and $6.21 \%$, and can be considered equivalent to the respective repeatability of the method. According to EU legislation (11) the typical repeatability should be between 18 and $24 \%$, for concentrations of 5 ng $\mathrm{mL}^{-1}$ (similar to the clenbuterol concentration of the incurred urine), and between 15 and $20 \%$, for concentrations of $18 \mathrm{ng}$ $\mathrm{g}^{-1}$ (similar to the clenbuterol concentration of the incurred liver), but the repeatability of the GC-MS method for urine and for liver samples, at similar concentrations, were found to range from 0.28 to $5.36 \%$, for the urine, and from 1.29 to $9.27 \%$, for the liver. The prosecution of the clenbuterol stability studies in both matrices was therefore possible. Moreover, the confirmation that liver has a uniform clenbuterol distribution, as stated by Gude and co-workers (16) is important for all those leading with sampling and analysis for official control, since it allows the collection of any part of this organ for residue monitoring.

The precision of the analytical methodology for clenbuterol determination in each type of sample, in intralaboratorial reproducibility conditions, had been estimated from daily calibrations curves in terms of the coefficient of variation of the method $(\mathrm{CVm})$. The knowledge of the $\mathrm{CVm}$ for clenbuterol determination in urine $(7.49 \%, n=59$, in the range 0 to 10 $\mathrm{ng} / \mathrm{mL})$ and liver $(9.20 \%, n=45$, in the range 0 to $24 \mathrm{ng} / \mathrm{g})$ is of extreme value for conclusions about clenbuterol stability.

The results from the clenbuterol stability studies in incurred urine and liver are shown in Figures 3 and 4. The average clenbuterol concentration and standard deviation in terms of $\mathrm{CV}$ of mean for all the results obtained in each study are shown in Tables 1 and 2. Those results for urine and for liver, at each storage condition, show a small $\mathrm{CV}$, each one closer of the

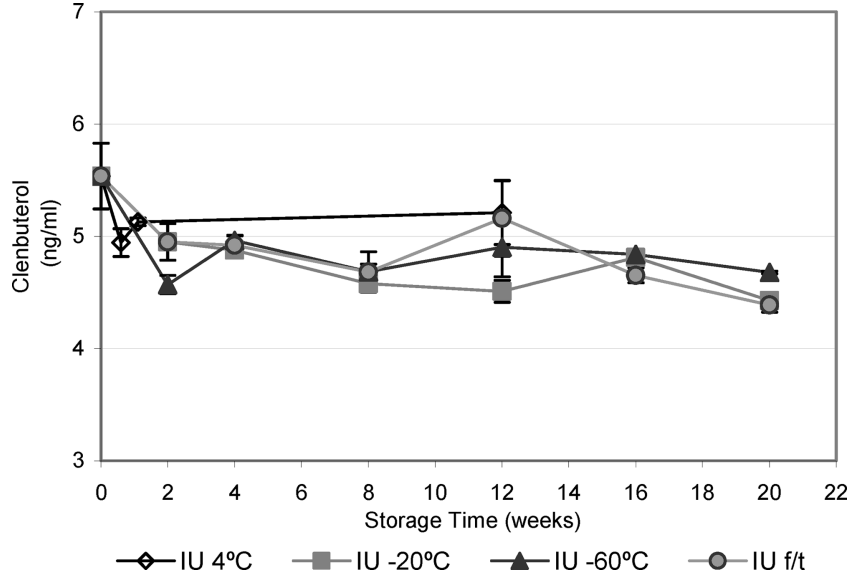

Figure 3. Stability study of clenbuterol in incurred urine (IU) stored at 4 ${ }^{\circ} \mathrm{C}$, at $-20^{\circ} \mathrm{C}$, at $-60^{\circ} \mathrm{C}$ and at successive freezing and thawing (f/t).

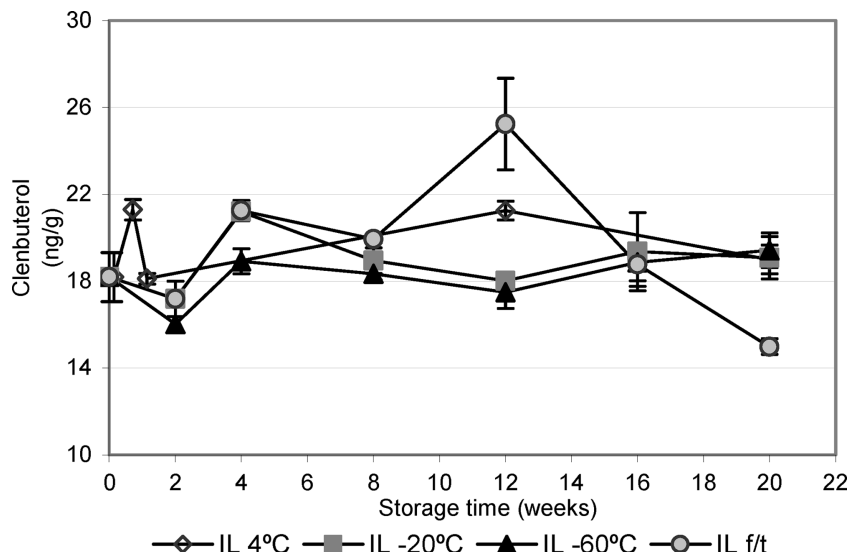

Figure 4. Stability study of clenbuterol in incurred liver (IL) stored at 4 ${ }^{\circ} \mathrm{C}$, at $-20^{\circ} \mathrm{C}$, at $-60^{\circ} \mathrm{C}$ and at successive freezing and thawing (f/t).

Table 1. Clenbuterol Concentration in Incurred Urine during Storage

\begin{tabular}{lcccc}
\hline $\begin{array}{c}\text { storage } \\
\text { conditions }\end{array}$ & $n$ & $\begin{array}{c}\text { av of clenbuterol } \\
\left(\mathrm{ng} \mathrm{mL}^{-1}\right)\end{array}$ & $\mathrm{CV}(\%)$ & $\begin{array}{c}\text { storage time } \\
\text { (weeks) }\end{array}$ \\
\hline $4{ }^{\circ} \mathrm{C}$ & 17 & 5.32 & 6.26 & 12 \\
$-20{ }^{\circ} \mathrm{C}$ & 26 & 4.97 & 9.63 & 20 \\
$-60^{\circ} \mathrm{C}$ & 24 & 5.06 & 8.62 & 20 \\
$6 \mathrm{f} / \mathrm{t}$ & 26 & 5.04 & 9.27 & 20 \\
\end{tabular}

Table 2. Clenbuterol Concentration in Incurred Liver during Storage

\begin{tabular}{lcccc}
\hline $\begin{array}{c}\text { storage } \\
\text { conditions }\end{array}$ & $n$ & $\begin{array}{c}\text { av of clenbuterol } \\
\left(\mathrm{ng} \mathrm{g}^{-1}\right)\end{array}$ & $\mathrm{CV}(\%)$ & $\begin{array}{c}\text { storage time } \\
\text { (weeks) }\end{array}$ \\
\hline $4^{\circ} \mathrm{C}$ & 22 & 19.13 & 8.30 & 20 \\
$-20^{\circ} \mathrm{C}$ & 28 & 18.68 & 7.56 & 20 \\
$-60{ }^{\circ} \mathrm{C}$ & 27 & 18.13 & 6.63 & 20 \\
$6 \mathrm{f} / \mathrm{t}$ & 28 & $19.07^{a}$ & $15.10^{a}$ & 20
\end{tabular}

${ }^{a}$ Rejecting data obtained at 12 weeks, the average clenbuterol concentration it will be of $18.33 \mathrm{ng} / \mathrm{g}$ with a coefficient of variation of $10.41 \%$.

respective $\mathrm{CVm}$, except for liver under successive freezings and thawings. Here a higher CV $(15.10 \%)$ was verified which could be explained by the elevated concentration obtained at 12 weeks of storage (coincident with the fourth thawing). This superior concentration could be explained by some kind of metabolic activity which was responsible eventually for increasing bioavailability of clenbuterol, from some clenbuterol conjugated forms which were not initially detectable due to aromatic and 
Table 3. Results of Stability Studies Performed by Regression Analyses Assuming Linearity in Incurred Urine

\begin{tabular}{lcccc}
\hline $\begin{array}{c}\text { storage } \\
\text { conditions }\end{array}$ & slope & $\begin{array}{c}\text { standard error } \\
\text { of slope }\end{array}$ & $P$ value & $\begin{array}{c}\text { storage time } \\
\text { (weeks) }\end{array}$ \\
\hline $4^{\circ} \mathrm{C}$ & -0.001 & 0.031 & 0.970 & 12 \\
$-20^{\circ} \mathrm{C}$ & -0.038 & 0.015 & 0.049 & 20 \\
$-60^{\circ} \mathrm{C}$ & -0.019 & 0.017 & 0.316 & 20 \\
$6 \mathrm{f} / \mathrm{t}$ & -0.037 & 0.015 & 0.054 & 20
\end{tabular}

Table 4. Results of Stability Studies Performed by Linear Regression Analyses Assuming Linearity in Incurred Liver

\begin{tabular}{lcccc}
\hline $\begin{array}{c}\text { storage } \\
\text { conditions }\end{array}$ & slope & $\begin{array}{c}\text { standard error } \\
\text { of slope }\end{array}$ & $P$ value & $\begin{array}{c}\text { storage time } \\
\text { (weeks) }\end{array}$ \\
\hline $4^{\circ} \mathrm{C}$ & 0.026 & 0.103 & 0.816 & 12 \\
$-20^{\circ} \mathrm{C}$ & 0.027 & 0.075 & 0.730 & 20 \\
$-60^{\circ} \mathrm{C}$ & 0.083 & 0.057 & 0.207 & 20 \\
$6 \mathrm{f} / \mathrm{t}$ & -0.057 & 0.194 & 0.782 & 20 \\
\hline
\end{tabular}

secondary amines reactions $(22,23)$ or as a result of protein aggregation or denaturation during the freeze and thaw cycles $(24,25)$. Is well-known that solute concentrations could vary significantly depending upon the type of freezing employed as well as the process scale, and this hypothesis should be considered in this case since the affected samples were those subjected to several freezing and thawing processes and not those subjected to a uniform temperature. Otherwise this abnormality could be justified only by random errors during analysis. Therefore it was not problematic for clenbuterol detection, and if rejecting the data obtained at 12 weeks, the average clenbuterol concentration will be of $18.33 \mathrm{ng} \mathrm{g}^{-1}$ with a coefficient of variation of $10.41 \%$, closer to the $\mathrm{CVm}$. Comparing the average of clenbuterol results obtained at all study temperatures for each matrix it could be seen that no one differed from data obtained at the $-60{ }^{\circ} \mathrm{C}$ studies, considered the best temperature for optimal results.

In addition, assuming a linear performance for clenbuterol concentration during storage, the data (average clenbuterol concentration obtained each day) from stability tests, at each set of storage conditions, was analyzed performing regression analyses. Results obtained for urine (Table 3) and for liver (Table 4) demonstrate that there was no tendency for clenbuterol degradation during storage, at any of the temperatures studied and storage times tested, since the slope obtained in each case does not deviate significantly from zero.

As it could be seen in these experiments, concerning clenbuterol determination, laboratorial samples of bovine urine or liver can be preserved at $+4{ }^{\circ} \mathrm{C}$ during, at least, 12 weeks, for urine, and 20 weeks, for liver, since clenbuterol remains without significant losses. Also, those samples can be stored at $-20{ }^{\circ} \mathrm{C}$ or at $-60{ }^{\circ} \mathrm{C}$ during at least 20 weeks, with no differences between these temperatures, and can be subjected to 6 freezings and thawings during that time since there was not a predictable significant loss of clenbuterol.

These conclusions allow one to contradict the opinion of Gigosos and co-workers (13), concerning urine, and amplified in the present work, for liver, about the risk of storing laboratorial samples of urine for clenbuterol residue control, because of the instability of clenbuterol in such a matrix.

The conclusions obtained in the present work are fundamental for official residue control in animal production since it validates the procedures implemented for laboratorial sampling, transport, storage and analysis. Bovine urine or liver samples collected for clenbuterol residue control can be transported at $+4{ }^{\circ} \mathrm{C}$, at least during $24-48 \mathrm{~h}$, or under freezing temperatures, and it could be possible to store samples for up to 5 months before screening or contra-analysis. Also samples can be frozen or thawed, at least 6 times, allowing defreezing during transportation without any consequence in final results, which is very important in the Azorean conditions. Moreover for the Azores the possibility of screening those samples in loco could be comparatively advantageous for meat certification and trade.

\section{LITERATURE CITED}

(1) Cristino, A.; Ramos, F.; Silveira, M. I. N. Control of the illegal use of clenbuterol in bovine production. J. Pharm. Biomed. Anal. 2003, 32, 311-316.

(2) Hanrahan, J. P. Beta-agonists and Their Effects on Animal Growth and Carcass Quality; Elsevier: London, 1987.

(3) Council Regulation 2377/90/EEC of 26 June 1990 laying down a Community procedure for the establishment of maximum residue limits of veterinary medicinal products in foodstuffs of animal origin. Off. J. Eur. Union 1990, L224, 1-8.

(4) Brambilla, G.; Cenci, T.; Franconi, F.; Galarini, R.; Macri, A.; Rondoni, F.; Strozzi, M.; Loizzo, A. Clinical and pharmacological profile in a clenbuterol epidemic poisoning of contaminated beef meat in Italy. Toxicol. Lett. 2000, 114, 47-53.

(5) Garay, J. B.; Jiménez, J. F. H.; Jiménez, M. L.; Sebastian, M. V.; Matesanz, J. P.; Moreno, P. M.; Galiana, J. R. Intoxicación por clenbuterol: datos clínicos y analíticos de un brote epidémico en Móstoles, Madrid. Rev. Clin. Esp. 1997, 197, 92-95.

(6) Martinez-Navarro, J. F. Food poisoning related to consumption of illicit $\beta$-agonist in liver. Lancet 1990, 336, 1311.

(7) Pulce, C.; Lamaison, D.; Keck, G.; Bostvironnois, C.; Nicolas, J.; Descotes, J. Collective human food poisonings by clenbuterol residues in veal liver. Vet. Hum. Toxicol. 1991, 33, 480-481.

(8) Sporano, V.; Grasso, L.; Esposito, M.; Oliviero, G.; Brambilla, G.; Loizzo, A. Clenbuterol residues in non-liver containing meat as a cause of collective food poisoning. Vet. Hum. Toxicol. 1998, 40, 141-143.

(9) Ramos, F.; Silveira, M. I. N.; Silva, J. M.; Barbosa, J.; Cruz, C.; Martins, J.; Neves, C.; Alves, C. Proposed guidelines for clenbuterol food poisoning. Am. J. Med. 2004, 117, 362.

(10) Barbosa, J.; Cruz, C.; Martins, J.; Silva, J. M.; Neves, C.; Alves, C.; Ramos, F.; Silveira, M. I. N. Food poisoning by clenbuterol in Portugal. Food Addit. Contam. 2005, 22, 563-566.

(11) Commission Decision 2002/657/CE of 12 August 2002 implementing Council Directive 96/23/EC concerning the performance of analytical methods and the interpretation of results. Off. J. Eur. Commun. 2002, L221, 8-35.

(12) Gude, Th.; Preiss-Weigert, A.; van Ginkel, L. A.; Dirscherl, C. Reference materials-bcr information-the certification of the clenbuterol and salbutamol concentrations in lyophilized bovine urinebcr-502-504. In Cunningham, N. F., Heitzman, R. J. (Report), European Commission EUR 19452/EN; Brussels, 2001.

(13) Gigosos, P. G.; Sampayo, C. F.; Abuín, C. F.; Sáez, A. C.; Belda, B. I. V. Effects of frozen storage on the recovery of clenbuterol from urine samples for official control. Food Addit. Contam. 2002, 19, 1010-1014.

(14) Pinheiro, I.; Jesuíno, B.; Barbosa, J.; Ramos, F.; Matos, J.; Silveira, M. I. N. Production of "in house" reference materials for ELISA screening of bovine urine and liver samples for clenbuterol. Accred. Qual. Assur. 2008, 13, 299-304.

(15) Gaspar, P.; van-Vyncht, G.; Scippo, M. L.; Maghuin-Rogister, G.; Kramer, G. N.; Gawlik, B. M.; Linsinger, T.; Lamberty, A.; van-Ginkel, L. A.; Dirscherl, C. Certification of the clembuterol mass concentration in lyophilised bovine liver reference materials with indicative information on the salbutamol and terbutaline mass concentrations, BCR-648 (b-agonist-free) and BCR-649 (bagonist-positive). EUR 20526/EN;Brussels, 2002.

(16) Gude, T.; Schmädicke, I.; Rahn, S.; Benesch-Girke, L.; Hashem, A.; Preiss, A.; Jülicher, B. The influence of the choice and the pretreatment of suitable tissue samples on the results of residue 
analyses using clenbuterol as an example. In Residues of veterinary drugs in food. Proceedings of the EuroResidue III conference; Haagsma, N., Ruiter, A., Eds.; Veldhoven: 1996; pp 157-161.

(17) Rose, M. D.; Shearer, G.; Farrington, W. H. H. The thermal stability and effect of cooking on veterinary drug residues in food: clenbuterol. Food Addit. Contam. 1995, 12, 67-76.

(18) Ramos, F.; Castilho, M. C.; Silveira, M. I. N. Estudo dos efeitos do processamento culinário sobre os resíduos de clembuterol e salbutamol em fígado de vitela. Rev. Port. Farm. 2000, L:3, 117123.

(19) Barone, R. Anatomie Comparée des Mamifères Domestique. Tome troisième. Splanchnologie I. Appareil digestif. Appareil respiratoire, 3rd ed.; Éditions Vogot: Paris, 1997.

(20) Montrade, M.-P.; le-Bizec, B.; Monteau, F.; Siliarte, B.; André, F. Multi-residue analysis for $\beta$-agonistic drugs in urine of meatproducing animals by gas chromatography-mass spectrometry. Anal. Chim. Acta 1993, 275, 253-268.

(21) Heitzman, R. J. Veterinary drug residues-Residues in food producing animals and their products-Reference materials and methods. CEC Report EUR 15127-EN, 2nd ed.; published on behalf of Commission of the European Communities, Blackwell Scientific Publications: Brussels, 1994.
(22) Boenish, B.; Quirke, J. F. Safety assessment of $\beta$-agonists. In Kuiper, H. A., Hoogenboom, L. A. P., In Vitro Toxicological Studies and Real Time Analysis of Residues in Food-FLAIR Concerted Action $\mathrm{N}^{\circ}$ 8-Proceedings of the Workshops held in Ghent, May 22-24, 1992 and Thessaloniki, October 30-31, 1992. Wageningen, 1992.

(23) Smith, D. J. The pharmacokinetics, metabolism, and tissue residues of $\beta$-adrenergic agonists in livestock. J. Anim. Sci. 1998, 76, 173194.

(24) Olsen, M. M.; Peron, G.; Godzdanker, R. Examination of Conventional Freeze Thaw Processing on Solute Distribution. National Biotechnology Conference, Boston (MD), 2006.

(25) Cao, E.; Chen, Y.; Cui, Z.; Foster, P. R. Effect of freezing and thawing rates on denaturation of proteins in aqueous solutions. Biotechnol. Bioeng. 2003, 82 (6), 684-690.

Received for review September 25, 2008. Revised manuscript received November 25, 2008. Accepted November 26, 2008. The authors are grateful to the Calouste Gulbenkian Foundation, to the Portuguese National Laboratory of Veterinarian Research (LNIV) and the Services of the Secretary of Agriculture and Forestry (SRAF) of the Regional Government of the Autonomous Region of the Azores, for the financial support of this research study.

JF802995E 